\title{
A CORRELATIONAL STUDY ON TERTIARY STUDENTS' READING HABITS AND THEIR CRITICAL READING SKILLS
}

\author{
By: \\ Iqbal Risca \\ Tridinanti University \\ ieqbal.id@gmail.com \\ Rahma Dianti \\ Tridinanti University \\ rahma_dianti@univ-tridinanti.ac.id
}

\begin{abstract}
Reading habit influences students' achievement of reading comprehension. It is assumed that if people have good reading habit, they will have good comprehension toward reading texts. The study was highlighted to examine the association between English education department students' reading habits and their critical reading skills. This study was conducted using a correlational research design. The population of this study consisted of 112 undegraduate students of English Education department of Tridinanti University. There were 37 students participating as the sample of the study chosen by using purposive sampling. In collecting the data, a questionnaire of reading habit and a critical reading test were distributed. A correlational analysis using Pearson Product Moment was applied to seek the association between the variables measured. Based on the data analysis result, it was found that students' reading habit was not significantly correlated with students' critical reading skills.
\end{abstract}

Keywords: correlational study, reading habits, critical reading skills

\section{INTRODUCTION}

Reading is one of verbal communications which helps people to access written information or even knowledge. By the advance of technology, the way people access written information is changing.

Nowadays, the information and knowledge can be read or accessed offline or online. In accessing or reading a text, the readers will involve their mind. Reading involves 
a cognitive process in which the reader's mind mentally takes part in communication with the author's mind during reading activity (Zare and Othman, 2013, p.188). When reading activity occurs, the readers activate their thinking to absorb the information in the text. There is an interaction between readers, their minds, and the text being read in understanding the writer's message or intention. When the readers read the text, they are not simply articulating the strings of sentences, but they are also converting the words, sentences, and paragraph into comprehensible messages that communicate something to them.

Reading activity balances its process and its product to gain comprehension as the goal of reading activity. Comprehension is a product of a driven process. Without meaningful process, there is no meaningful product. The readers need to go beyond the text to gain comprehension. In addition, reading activity engages the text parts and readers' personal experience in meaning construction process (Shihab, 2011). It means that gaining a comprehension during reading is not a simple activity. It demands the readers to apply certain processes, strategies, or even skills. The readers will link their prior knowledge with the current information from the text, they will try to make meaning from the information, and then they will interpret the information based on their understanding. When the readers can interpret the valid information as the writer's intention, it is the signals that the readers comprehend what they are reading. It is a crystal clear that in advanced reading activity, the 
readers are asked to read beyond the In processing academic reading lines. The active readers need to sources, the students can not merely criticize the reading passages by apply skimming or scanning, but they analyzing the writer's intention, also need to critically analyze and evaluating the ideas provided in the evaluate the information to make text, and interpreting a set of new valid meaning or interpretation from built-in information from reading reading sources. Reading critically activity.

needs the readers to involve the skills

Reading skill holds a vital role for academic success in tertiary level. The success of academic achievement requires an effective reading since reading is the most important avenue Critical reading is a more active for effective learning (Palani, 2012). They need to have purpose in their mind when reading. They need to ask, to argue, to be skeptic during processing the reading passage. This skill enables the students to struggle and reach success in their academic life since they need to access abundant reading sources online or extent to which the authors have offline to complete the school tasks. provided enough reasonable evidence 
for the claims they make (Wallace and Wray, 2011). Besides, it involves a deeper and more complex engagement with a text since critical reading demands the readers to make inference by reasoning, questioning, evaluating, and drawing conclusion (Adali, 2011). When we critically read a passage, we are questioning or arguing to analyze and evaluate the information we find in the text before we make interpretation or critical conclusion about what we have read.

To be critical in reading is not instant. It needs process. The readers can be a good reader if they are fond reading since early. Reader has a good reading habit when she or he has a strong love of reading and desire to read all throughout his lifetime. Kropp (2016) suggests that promoting reading habits since early can contribute positive effects to human's intellect and language development, for example they will have good vocabulary mastery, communicative skill, critical thinking, literacy skill and positive mind set. In addition, good reading habits play an essential role as a strong weapon for the students to succeed in life (Bashir and Mattoo, 2012). Suhana and Haryudin (2017) found that there was a significant effect of reading habit toward the students' reading comprehension. It confirms that reading habit can influence someone's ability in comprehending a reading text. However, the level of reading skill in Indonesia is still low. It was revealed by the latest PISA survey in 2015 which showed that the mean score of reading skill was 397 out of 493 (OECD, 2017). This condition is problem in Indonesia. It is believed that this problem was 
influenced by lacking reading habits. explanation above, the writers The lack of reading habits can intended to conduct a study to influence to the students' competence examine the association between in understanding the text being read. $\quad$ English Department students' reading

The low level of reading habit in Indonesia was caused by several habit and their critical reading skill at Tridinanti University Palembang.

factors, such as: reading is not a habit for Indonesian people, less book availability, most of Indonesian people cannot afford the book, they mostly spend their time on television, internet, and other multimedia (Mustafa, 2012). Those factors can contribute to the low level of reading habit. It has become an issue of growing concern among education and often cited as a cause for the decline in people reading habit.

\section{Based on the previous} elaboration, the writer assumed that students' reading habit could influence their critical reading achievement. On the basis of the

\section{METHODOLOGY}

The writers used a correlational study to conduct the investigation since it was the best design to verify the hypotheses of the study. The objective of the research was to examine whether students' reading habit has correlation to their critical reading skill.

The research would be conducted through the following procedures: 1) addressing the research problems and objective; 2) determining the research design; 3) selecting and constructing the research instruments; 4) collecting the 
data; 5) analyzing the data; 6) were a questionnaire of reading habit answering the research problem; and and a critical reading test. The 7) reporting the research result. The research procedure is portrayed in Figure 1.

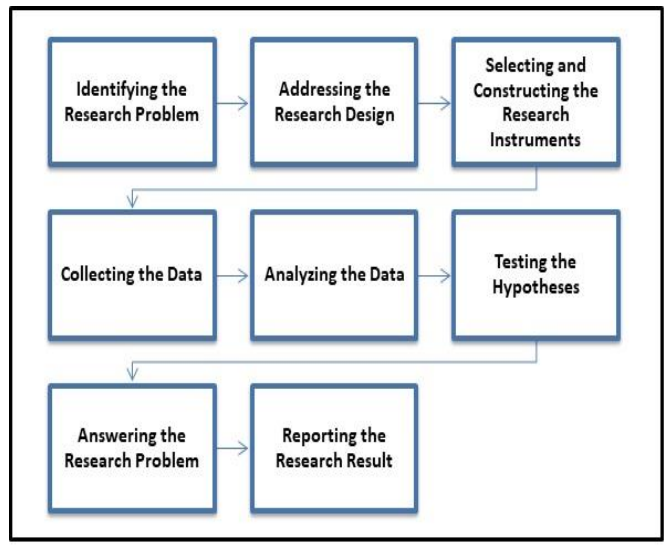

Figure 1. Research Procedures

The research involved the tertiary students of English Education Department of University of Tridinanti. There were 37 students who participated as the object of the research chosen by using purposive sampling. The researchers selected the students who had taken critical reading subject.

The researchers adopted two instruments to obtain the data; those questionnaire was used to gather the data of students' reading habit. It was adopted from Janthong and Sripetpun (2010) and consisted of 20 items. The items measured the aspects of reading attitude (10 items), reading frequency (4 items), book categories (3 items), and reading access (3 items).

Next, a critical reading test was administered to collect the data dealing with the students' critical reading skill. The test consisted of 20 items of multiple choices, and it was adopted from Davenport (2007). This test measured critical reading subskills as follows: interpreting meaning from context, evaluating writer's purpose and intention, making inferences, evaluating evidence, and evaluating cause and effect. 
After collecting the data, the researchers would analyze it using correlational analysis. Pearson Product Moment was run to inferentially seek the association between the variables measured.

\section{RESULT AND DISCUSSION}

Based on the result of reading habit questionnaire, it was found that the highest score was 88 , the lowest score was 55, the mean score was 72.32, and the standard deviation was 7.08. Meanwhile, the result of critical reading test showed that the student's highest score was 75 , the lowest score was 20 , the mean score was 36.22 , and the standard deviation was 13.81 . The results of students' reading habit and critical reading test are summarized in Table 1.
Table 1

The Results of Students' Reading Habit and Critical Reading Test

\begin{tabular}{ccccc}
\hline Variables & Min & Max & Mean & $\begin{array}{c}\text { Std. } \\
\text { Dev. }\end{array}$ \\
\hline $\begin{array}{c}\text { Reading } \\
\text { Habit }\end{array}$ & 55 & 88 & 72.32 & 7.083 \\
$\begin{array}{c}\text { Critical } \\
\text { Reading } \\
\text { Skill }\end{array}$ & 20 & 75 & 36.22 & 13.815 \\
\hline
\end{tabular}

Based on the frequency analysis, it was revealed that out of 37 students, 19 students had good reading habit. It indicated that most of the students were fond of reading activity. Whereas the result of frequency analysis of students' critical reading showed that mostly students $(86.49 \%)$ were categorized as poor in critical reading skill. It indicated that even though most of the students fond at reading; they were not a critical reader. This condition might be caused by the students' choice of reading books. Most of students $(83 \%)$ agreed that they read the books when they had spare time and the book choices were comics, 
news, documentaries, and short

Table 12

stories.

\section{A correlational analysi}

Pearson Product Moment was applied to verify the hypotheses. Based on the result of the correlational analysis, it was found that $r$-value was -0.237 . It meant that the correlation level between the students' reading habit and their critical reading skill were weak. The students' reading did not influence the students' critical reading skill. Moreover, the significant value ( $\rho$-value) of the correlation analysis was 0.158 which was higher than 0.05 . It indicated that there was no significant relationship between the variables measured. Those findings verified that there was no correlation between students' reading habit and critical reading skills. The summary of Correlation Analysis is presented in Table 2.

\begin{tabular}{cc}
\multicolumn{2}{c}{ The Result of Correlation Analysis } \\
\hline Correlation & $\begin{array}{c}\text { Reading Habit and Critical } \\
\text { Reading skill }\end{array}$ \\
\hline Pearson Correlation (r) & -0.237 \\
Sig. (2-tailed) & 0.158 \\
N & 37 \\
\hline
\end{tabular}

Based on the findings of the study, there were some interpretations that could be drawn. First, students reading habit was categorized good. It indicated that most of the students fond at reading. However, the purpose of reading was for pleasure. It was highlighted from their choices of book categories they liked to read.

Second, the result of correlational analysis revealed that there was no correlation between students' reading habits and their critical reading skills. It means that the results of this study did not correspond with the researchers' initial assumption that reading habit could influence critical reading skillIt might be influenced by the lack of vocabulary mastery and their choices 
to the books they consumed. The students could not comprehend the academic texts because they had different level of vocabulary stock.

Third, it was revealed that the students' critical reading skill was categorized as poor. The students were not able to analyze and evaluate the information from the reading passages. Meanwhile, academic reading demands the readers to be critical by applying some skills, such as reasoning, evaluating, interpreting and drawing conclusion (Adali, 2011; Comber and Nixon, 2011). The low level of critical reading skill might be caused by lacking academic reading activities. They seldom read academic reading passages. Therefore, they could not process the passages effectively. It was in line with Thanuskodi (2011) who affirms that by reading habitually, readers can train their mind to work effectively. This condition was also influenced by their vocabulary stock. They had limited stock of academic vocabulary. It also influenced their skills to analyze and evaluate critical reading passages.

Lastly, it was revealed that students' reading habit was not significantly correlated with their critical reading skill. The level of association between reading habit and critical reading was weak and reading habit was not positively influenced the students' critical reading skill. It was not in line with what had been found by Wulandari (2016) that reading habit had a positive correlation with reading comprehension. Although the students' reading habit was in the good level, it did not influence their critical reading level. They read the 
books for pleasure purpose. It is highlighted from the books they choose to read. They just read for fun, such as reading comics, novels, and magazines.

\section{CONCLUSION}

The results of the study showed that the students' reading habits were not correlated with their critical reading skills. Dealing with the result, there were some conclusions could be made. First, a good level of students' reading habit will not simply influence students' reading skill, especially critical reading skill. When the students are fond at reading, it does not mean they can struggle for academic reading activity. Second, reading purposes influence the readers' choice in selecting the book they read. Third, it is an urgent that every teacher in tertiary level to raise their awareness that students' critical reading skill should be promoted through academic reading activities.

\section{REFERENCES}

Adali, O. (2011). Understand and tell. Pan Publishing.

Bashir, I., \& Mattoo, N. H. (2012). A study on habits and academic among adolescents (14-19) years. International Journal of Social Science Tomorrow, 1(5), $1-5$.

Comber, B., \& Nixon, H. (2011). Critical reading comprehension in an era of accountability. Australian Educational Researcher, 38(2), 167-179. https://doi.org/10.1007/s13384011-0022-z

Davenport, T. R. (2007). Mastering the SAT critical reading test. Wiley Publishing, Inc.

Duncan, J. (2014). Reading critically. The Writing Centre.

Janthong, J., \& Sripetpun, W. (2010). English reading comprehension and reading habit improvement: use of questioning technique. The 2nd International Conference on Humanities and Social Sciences, 1-31.

Kropp, M. (2016). 7 ways to promote positive reading habits for older children.

https://www.washingtonpost.co 
$\mathrm{m} /$ news/parenting/wp/2016/08/2 4/7-ways-to-promote-positivereading-habits-for-olderchildren/

Mustafa, B. (2012). Indonesian people reading habit is very low: How libraries can enhance the people reading habit. http://consalxv.perpusnas.go.id/u ploaded_files/pdf/papers/normal/ ID_B_Mustafa-paper-readinghabit.pdf.

OECD. (2017). PISA 2015 results: Executive summary. Paris: OECD Publishing.

Palani, K. K. (2012). Promoting reading habits and creating literate society. Journal of Arts,Science \& Commerce, 3(2), 90-94.

Shihab, I. A. (2011). Reading as critical thinking. Asian Social Science, 7(8), 209-218. https://doi.org/10.5539/ass.v7n8 p209

Suhana, A., \& Haryudin, A. (2017). the effects of reading habit towards students' reading comprehension at private senior high School in Purwakarta. ELTIN JOURNAL, Journal of English Language Teaching in Indonesia, 5(2), 57. https://doi.org/10.22460/eltin.v5i 2.p57-70

Thanuskodi, S. (2011). Reading habit among library and information science students. Annamalai University: A survey. International Journal Education Science, 3(2), 1-11.
Wallace, M., \& Wray, A. (2011). Critical reading and writing for postgraduates (2nd Ed.). London: Sage Publication Ltd.

Wulandari, R. (2016). The correlation between students' reading habit and students' critical reading skills in the first grade of SMP PGRI 1 Gunung Pelindung, east Lampung. Unpublished Thesis: Universitas Lampung.

Zare, P., \& Othman, M. (2013). The relationship between language learning strategy use and reading comprehension achievement among iranian undergraduate EFL learners. World Applied Sciences Journal, 3(13), 187193. 